\title{
Thermoanaerobacter uzonensis sp. nov., an anaerobic thermophilic bacterium isolated from a hot spring within the Uzon Caldera, Kamchatka, Far East Russia
}

Correspondence Juergen Wiegel jwiegel@uga.edu

\author{
Isaac D. Wagner, ${ }^{1}$ Weidong Zhao, ${ }^{2,3}$ Chuanlun L. Zhang, ${ }^{2,3}$ \\ Christopher S. Romanek, ${ }^{3,4}$ Manfred Rohde $^{5}$ and Juergen Wiegel ${ }^{1}$ \\ 1Department of Microbiology, University of Georgia, Athens, GA 30602, USA \\ ${ }^{2}$ Department of Marine Sciences, University of Georgia, Athens, GA 30602, USA \\ ${ }^{3}$ Savannah River Ecology Laboratory, University of Georgia, Aiken, SC 29802, USA \\ ${ }^{4}$ Department of Geology, University of Georgia, Athens, GA 30602, USA \\ ${ }^{5} \mathrm{HZI}$ - Helmholtz Centre for Infection Research, Inhoffenstrasse 7, D-38124 Braunschweig, Germany
}

Several strains of heterotrophic, anaerobic thermophilic bacteria were isolated from hot springs of the Uzon Caldera, Kamchatka, Far East Russia. Strain JW/IW010 ${ }^{\top}$ was isolated from a hot spring within the West sector of the Eastern Thermal field, near Pulsating Spring in the Winding Creek area. Cells of strain JW/IW $010^{\top}$ were straight to slightly curved rods, $0.5 \mu \mathrm{m}$ in width and variable in length from 2 to $5 \mu \mathrm{m}$ and occasionally up to $15 \mu \mathrm{m}$, and formed oval subterminal spores. Cells stained Gram-negative, but were Gram-type positive. Growth was observed between 32.5 and $69{ }^{\circ} \mathrm{C}$ with an optimum around $61{ }^{\circ} \mathrm{C}$ (no growth occurred at or below $30{ }^{\circ} \mathrm{C}$, or at or above $72{ }^{\circ} \mathrm{C}$ ). The $\mathrm{pH}^{60}{ }^{\circ} \mathrm{C}$ range for growth was 4.2-8.9 with an optimum at 7.1 (no growth occurred at or below $\mathrm{pH}^{60}{ }^{\circ} \mathrm{C} 3.9$, or at 9.2 or above). The shortest observed doubling-time at $\mathrm{pH}^{60}{ }^{\circ} \mathrm{C} 6.9$ and $61{ }^{\circ} \mathrm{C}$ was $30 \mathrm{~min}$. Strain JW/IW010 ${ }^{\top}$ was chemo-organotrophic; yeast extract, peptone, Casamino acids and tryptone supported growth. Yeast extract was necessary for the utilization of non-proteinaceous substrates, and growth was observed with inulin, cellobiose, maltose, sucrose, glucose, fructose, galactose, mannose, xylose, trehalose, mannitol, pyruvate and crotonate. The $\mathrm{G}+\mathrm{C}$ content of the genomic DNA of strain JW/IW010 ${ }^{\top}$ was $33.6 \mathrm{~mol} \%$ (HPLC method). The major phospholipid fatty acids were iso-15:0 (53.5\%), $15: 0$ (11.8\%), $16: 0$ (7.3\%), 10-methyl $16: 0(7.3 \%)$ and anteiso-15:0 (5.3\%). 16S rRNA gene sequence analysis placed strain JW/ IW010 ${ }^{\top}$ in the genus Thermoanaerobacter of the family 'Thermoanaerobacteriaceae' (Firmicutes), with Thermoanaerobacter sulfurigignens JW/SL-NZ826 ${ }^{\top}$ (97\% $16 \mathrm{~S}$ rRNA gene sequence similarity) and Thermoanaerobacter kivui DSM $2030^{\top}$ (94.5\%) as the closest phylogenetic relatives with validly published names. The level of DNA-DNA relatedness between strain JW/ IW010 ${ }^{\top}$ and Thermoanaerobacter sulfurigignens JW/SL-NZ826 ${ }^{\top}$ was $64 \%$. Based on the physiological, phylogenetic and genotypic data, strain $\mathrm{JW} / \mathrm{IW} 010^{\top}$ represents a novel taxon, for which the name Thermoanaerobacter uzonensis sp. nov. is proposed. The type strain is JW/ IW010 ${ }^{\top}$ (=ATCC BAA-1464 ${ }^{\top}=$ DSM $18761^{\top}$ ). The effectively published strain, $1501 / 60$, of 'Clostridium uzonii' [Krivenko, V. V., Vadachloriya, R. M., Chermykh, N. A., Mityushina, L. L. \& Krasilnikova, E. N. (1990). Microbiology (English translation of Mikrobiologiia) 59, 741-748] had approximately $88.0 \%$ DNA-DNA relatedness with strain $\mathrm{JW} \mathrm{IW} 010^{\top}$ and was included in the novel taxon.

Abbreviations: AMC, 7-amino-4-methylcoumarin; 4MU, 4-methylumbelliferone; PLFA, phospholipid fatty acid.

The GenBank/EMBL/DDBJ accession number for the 16S rRNA gene sequence of strain JW/IW010 ${ }^{\top}$ is EF530067.
The Uzon Caldera and Geyser Valley region of Kamchatka contain a wide variety of old and recently formed geothermal features in close proximity. Water and sediment samples were collected from hot springs of the Uzon Caldera and, concomitantly, temperature and $\mathrm{pH}$ 
measurements were taken and geochemical properties were assessed. For the isolation of novel anaerobic thermophilic prokaryotes, enrichment cultures were prepared from Uzon Caldera hot spring water and sediment samples using various carbon substrates, including methanol, crotonate, glucose, fructose and xylose.

The enrichment cultures were prepared using an anaerobic, carbonate-buffered basal medium $\left[2 \mathrm{mM} \mathrm{KH}_{2} \mathrm{PO}_{4}, 0.5 \mathrm{~g}\right.$ $\mathrm{NH}_{4} \mathrm{Cl} \mathrm{l}^{-1}, 0.5 \mathrm{~g}\left(\mathrm{NH}_{4}\right)_{2} \mathrm{SO}_{4} \mathrm{l}^{-1}, 1.5 \mathrm{~g} \mathrm{NaHCO}_{3} \mathrm{l}^{-1}$, $0.1 \mathrm{mM} \mathrm{MgCl}, 0.1 \mathrm{mM} \mathrm{CaCl}_{2}, 1.0 \mathrm{ml}$ vitamin solution $\mathrm{l}^{-1}$ and $1.0 \mathrm{ml} \mathrm{Na}_{2} \mathrm{SeO}_{3}-\mathrm{Na}_{2} \mathrm{WO}_{3}$ trace-element solution $\mathrm{l}^{-1}$ (Widdel \& Bak, 1992)] at a $\mathrm{pH}^{25{ }^{\circ} \mathrm{C}}$ of 6 , supplemented with $3 \mathrm{~g}$ carbon substrate $\mathrm{l}^{-1}$ and $1 \mathrm{~g}$ yeast extract $\mathrm{l}^{-1}$. From enrichment cultures with visible growth, pure cultures were obtained using serial dilutions in anaerobic agar-shake-roll tubes with the carbonate-buffered basal medium supplemented with $2.15 \%$ agar (Ljungdahl \& Wiegel, 1986) and multiple rounds of colony isolation. Purity was checked microscopically and by means of $16 \mathrm{~S}$ rRNA gene sequencing.

Strains JW/IW007, JW/IW010 ${ }^{\mathrm{T}}$ and JW/IW015 were derived from water and sediment samples from a small pool $2 \mathrm{~m}$ east of Pulsating Spring $\left(54.5007^{\circ} \mathrm{N} 160.0076^{\circ}\right.$ E), which had a temperature of about $77{ }^{\circ} \mathrm{C}$ and a $\mathrm{pH}$ of 5.6. These pools feed Winding Creek, which is located on the northern side of the central portion of the Uzon Eastern Thermal field and flows southwards into Chloride Lake. Strain JW/IW007 was isolated using methanol as the provided carbon substrate. Axenic cultures of strains JW/ IW $010^{\mathrm{T}}$ and JW/IW015 were isolated using crotonate as the carbon substrate. Similarly, strain JW/HL-KA15 was isolated from a glucose-supplemented enrichment from the hot spring 'Blue Pool', located at the Northern Thermal field $\left(78.8{ }^{\circ} \mathrm{C}\right.$ and $\left.\mathrm{pH} 6.3\right)$.

In order to check culture purity and for phylogenetic analyses, DNA was extracted using an UltraClean DNA isolation kit (Mo Bio) and 16S rRNA gene sequences were PCR-amplified and sequenced. Routine PCRs were prepared with the bacterial domain-specific primer set $27 \mathrm{~F}$ and $1492 \mathrm{R}$ (Lane, 1991), using GoTaq (Promega) and the thermocycler conditions described previously by Lee et al. (2005). The $16 \mathrm{~S}$ rRNA gene sequence of strain JW/IW010 ${ }^{\mathrm{T}}$ was amplified using high-fidelity, PrimeStar HS polymerase (Takara Mirus Bio). Amplification with PrimeStar HS polymerase proceeded with thermocycler conditions of $10 \mathrm{~s}$ at $98{ }^{\circ} \mathrm{C}, 5 \mathrm{~s}$ at $58{ }^{\circ} \mathrm{C}$ and $90 \mathrm{~s}$ at $72{ }^{\circ} \mathrm{C}$, repeated for a total of 30 cycles. The amplified 16S rRNA gene sequences were purified using a QIAquick PCR purification kit (Qiagen) and sequenced by Macrogen. Sequencing results were aligned using Sequencher v4.1.4 (Gene Codes) and a multiple sequence alignment was created with CLUSTAL W (Thompson et al., 1994). Editing of alignments was performed using GeneDoc v2.6.001 (Nicholas \& Nicholas, 1997). The phylogenetic tree (Fig. 1) was inferred by using the neighbour-joining method (Saitou \& Nei, 1987) with the Jukes and Cantor model (Jukes \& Cantor, 1969), using the PHYLIP v3.6a2.1 phylogenetic analysis package (Felsenstein, 2001).
From the 16S rRNA gene sequence analysis, strain JW/ IW $010^{\mathrm{T}}$ and related strains were clearly placed in the genus Thermoanaerobacter of the family 'Thermoanaerobacteriaceae' (Firmicutes) (Fig. 1). Subsequent $16 \mathrm{~S}$ rRNA gene sequence-based phylogenetic analyses revealed that strain JW/IW $010^{\mathrm{T}}$ had a high similarity $(99 \%)$ to strain $1501 / 60$ with the effectively, but not validly, published name 'Clostridium uzonii' (Krivenko et al., 1990). 'C. uzonii' has been described as a deeply branching member of the Clostridium cluster V, which contains the genus Thermoanaerobacter (Stackebrandt et al., 1999). Based on 16S rRNA gene sequence analysis, the closest phylogenetic relatives with validly published names were Thermoanaerobacter sulfurigignens JW/SL-NZ826 ${ }^{\mathrm{T}}$ (97\% similarity) (Lee et al., 2007a) and the acetogenic Thermoanaerobacter kivui DSM $2030^{\mathrm{T}}$ (96\% similarity) (Onyenwoke \& Wiegel, 2008). Strains 1501/60 (DSM 9752) and 1611 (DSM 9753), effectively described by Krivenko et al. (1990), were isolated from a mud cauldron and hydrothermal silt, respectively, within the Uzon Caldera and were obtained from the German Collection of Microorganisms and Cell Cultures for comparison with strain $\mathrm{JW} / \mathrm{IW} 010^{\mathrm{T}}$. Thermoanaerobacter sulfurigignens JW/SL-NZ826 ${ }^{\mathrm{T}}$ was obtained from laboratory stock.

Within agar-shake-roll tubes, colonies of strain JW/IW $010^{\mathrm{T}}$ were visible following overnight incubation at $60^{\circ} \mathrm{C}$; the colonies were circular, 1-2 $\mathrm{mm}$ in diameter, slightly convex and creamy white in colour. When grown on plates of carbonate-buffered basal medium with $2.3 \%$ agar within anaerobic jars at $60{ }^{\circ} \mathrm{C}$, strain JW/IW010 ${ }^{\mathrm{T}}$ formed colourless, nearly transparent circular colonies up to $1 \mathrm{~mm}$ in diameter, whereas Thermoanaerobacter sulfurigignens JW/SL-NZ826 ${ }^{\mathrm{T}}$ formed circular colonies of up to $1 \mathrm{~mm}$ in diameter that were opaque and bluish white in colour. Cells of strain JW/IW010 ${ }^{\mathrm{T}}$ were rod-shaped, straight to slightly curved and approximately $0.5 \mu \mathrm{m}$ in width and 2$5 \mu \mathrm{m}$ in length (Figs 2 and 3). Occasionally, cells up to $15 \mu \mathrm{m}$ in length were observed. Shorter or longer chains of cells frequently contained intermittent coccoid cells (Fig. 3), typical of Thermoanaerobacter (Wiegel \& Ljungdahl, 1981). Gram stain reactions were performed on both early exponential and stationary growth phase cultures of strain JW/IW010 ${ }^{\mathrm{T}}$ using Fisherbrand Gram $\sqrt{ }$ Control/Test Slides (Thermo Fisher Scientific). Strain JW/IW010 ${ }^{\mathrm{T}}$ stained Gram-negative under both growth conditions although phylogenetically it is Gram-type positive (Wiegel, 1981).

Sporulation of strain JW/IW $010^{\mathrm{T}}$ was observed, though only rarely. Spores were oval, located subterminal to terminal and caused the mother cell to swell (Fig. 2a). Viable subcultures were obtained from liquid cultures heated to $100{ }^{\circ} \mathrm{C}$ for $5 \mathrm{~min}$. Although sporulation was rarely seen in strain JW/IW $010^{\mathrm{T}}$, other Thermoanaerobacter species also produce spores infrequently, whereas sporulation has never been observed in other taxa of this genus, e.g. Thermoanaerobacter ethanolicus JW $200^{\mathrm{T}}$ (Onyenwoke \& Wiegel, 2008; Wiegel \& Ljungdahl, 1981). Cells of strain JW/IW $010^{\mathrm{T}}$ had peritrichously inserted 


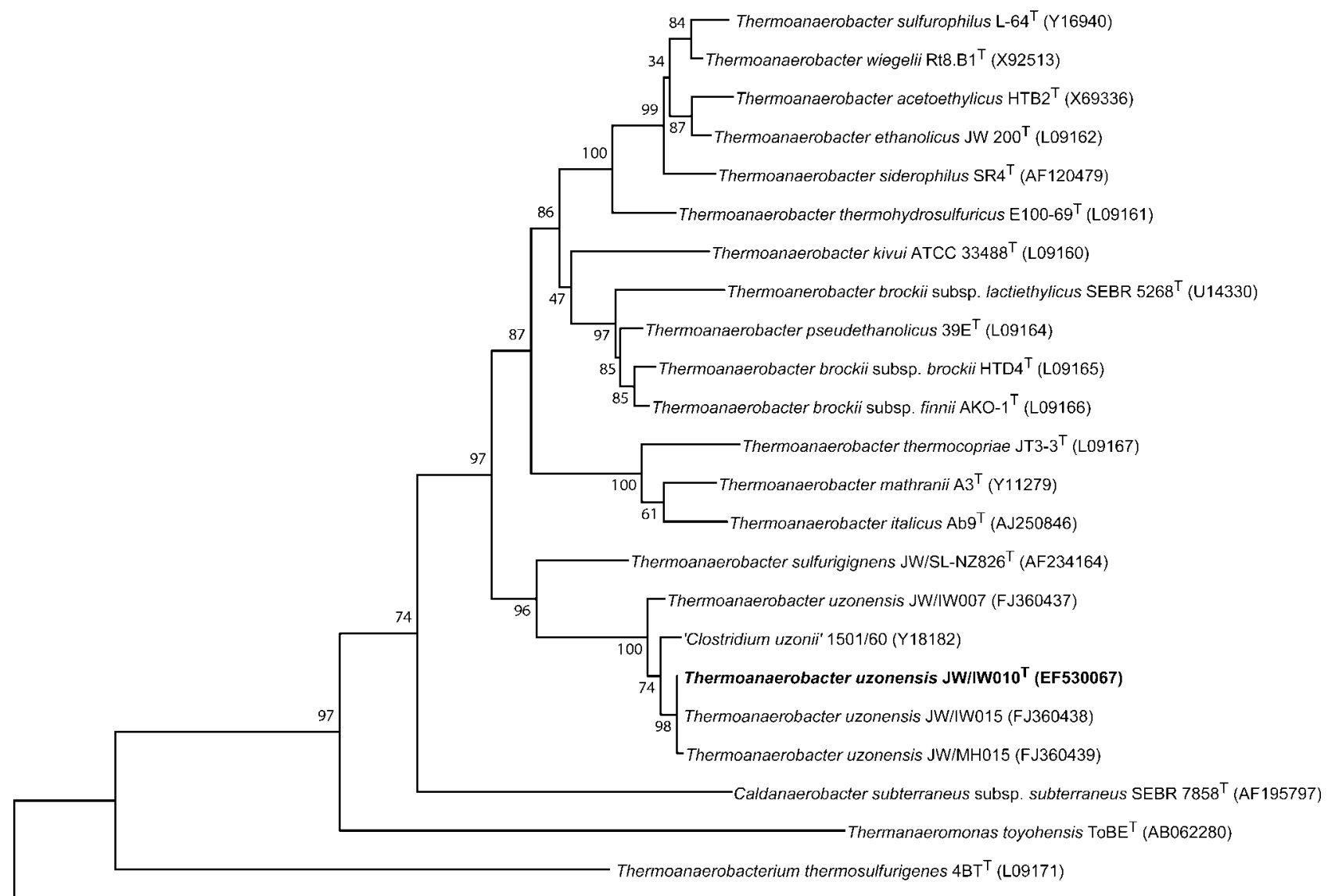

Clostridium butyricum ATCC $19398^{\top}$ (AB075768

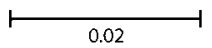

Fig. 1. 16S rRNA gene sequence-based phylogenetic dendrogram of strains JW/IW007, JW/IW010 ${ }^{\top}$, JW/IW015 and JW/MH015 amongst members of the genus Thermoanaerobacter and selected members of the family 'Thermoanaerobacteriacae'. Clostridium butyricum was used as an outgroup; numbers at nodes are bootstrap percentages (100 replicates). The tree was constructed using the neighbour-joining method (Saitou \& Nei, 1987) and the Jukes and Cantor distance corrections (Jukes \& Cantor, 1969). Bar, 2 nucleotide substitutions per 100 nucleotides.

flagella (Fig. 3) and tumbling motility was observed when liquid cultures were viewed using phase-contrast microscopy. When grown in media containing 50 or $100 \mathrm{mM}$ thiosulphate, cells of strain JW/IW $010^{\mathrm{T}}$ were more motile compared with cells grown in medium lacking thiosulphate.

The temperature and $\mathrm{pH}$ profiles, substrate range and tolerance of thiosulphate and sulphite were determined through measurement of $\Delta \mathrm{OD}_{600}$ using a Spectronic 21 spectrophotometer (Bausch and Lomb). A temperaturegradient incubator (Scientific Industries) was used to determine the temperature range and optimum for growth of strain JW/IW $010^{\mathrm{T}}$ using the aforementioned basal carbonate-buffered medium complemented with $4 \mathrm{~g}$ glucose $\mathrm{l}^{-1}$ and $2 \mathrm{~g}$ yeast extract $\mathrm{l}^{-1}$. Up to $96 \mathrm{~h}$, growth was observed between $32.5-69{ }^{\circ} \mathrm{C}$, with optimum growth at $61{ }^{\circ} \mathrm{C}$; growth was not observed at or below $30{ }^{\circ} \mathrm{C}$, or at or above $72{ }^{\circ} \mathrm{C}$ (Fig. 4a). Media used for the determination of the $\mathrm{pH}$ range of strain $\mathrm{JW} / \mathrm{IW} 010^{\mathrm{T}}$ was buffered with $10 \mathrm{mM}$ of each trisodium citrate, MES, Tris and $\mathrm{Na}_{2} \mathrm{CO}_{3}$, rather than $\mathrm{NaHCO}_{3}$, and also contained 4 g glucose $\mathrm{l}^{-1}$ and $2 \mathrm{~g}$ yeast extract $\mathrm{l}^{-1}$. Up to $75 \mathrm{~h}$, growth was observed between an initial $\mathrm{pH}^{60}{ }^{\circ} \mathrm{C}$ of 4.2-8.9, with an optimum at 7.1; no growth was observed at or below $\mathrm{pH}^{60}{ }^{\circ} \mathrm{C} 3.9$, or at 9.2 or above (Fig. 4b). The shortest doubling-time for strain JW/IW $010^{\mathrm{T}}$ was approximately $30 \mathrm{~min}$ and occurred at $\mathrm{pH}^{60}{ }^{\circ} \mathrm{C} 6.9$ and $61{ }^{\circ} \mathrm{C}$ in medium containing $2 \mathrm{~g}$ yeast extract $1^{-1}$ and 4 g glucose $1^{-1}$. No growth was observed in the absence of yeast extract while using glucose as a carbon source. Using $0.5 \mathrm{~g}$ yeast extract $1^{-1}$ as the sole substrate led only to limited growth. Proteinaceous carbon sources added to the carbonate-buffered basal medium to a concentration of $5 \mathrm{~g} \mathrm{l}^{-1}$ were tested for their ability to support the growth of strain JW/IW010 ${ }^{\mathrm{T}}$. Growth was assumed when $\Delta \mathrm{OD}_{600}$ increased or when cell numbers 


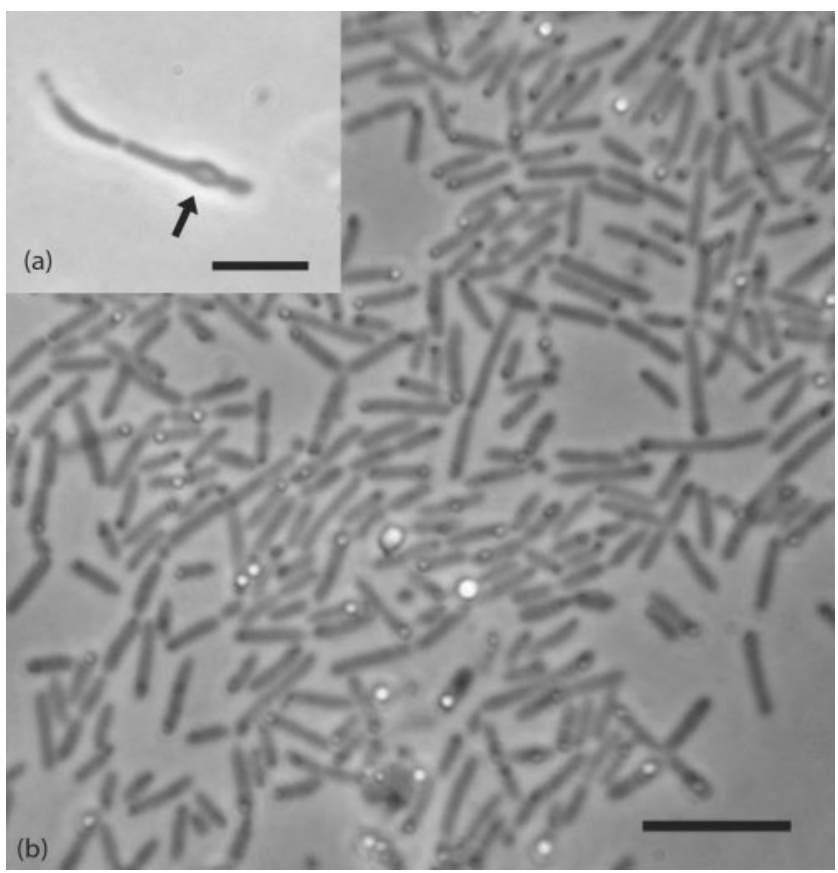

Fig. 2. Morphology of cells of strain $\mathrm{JW} / \mathrm{IW} 010^{\top}$, studied using an Olympus VANOX phase-contrast microscope (Tokyo, Japan). (a) Spore formation within a cell of strain JW/IW010 ${ }^{\top}$. The arrow indicates the position of oval spores within the swollen mother cell. Bar, $5 \mu \mathrm{m}$. (b) Sulphur granula within cells of strain JW/IW010 grown for approximately $24 \mathrm{~h}$ in medium containing $50 \mathrm{mM}$ thiosulphate. Bar, $10 \mu \mathrm{m}$.

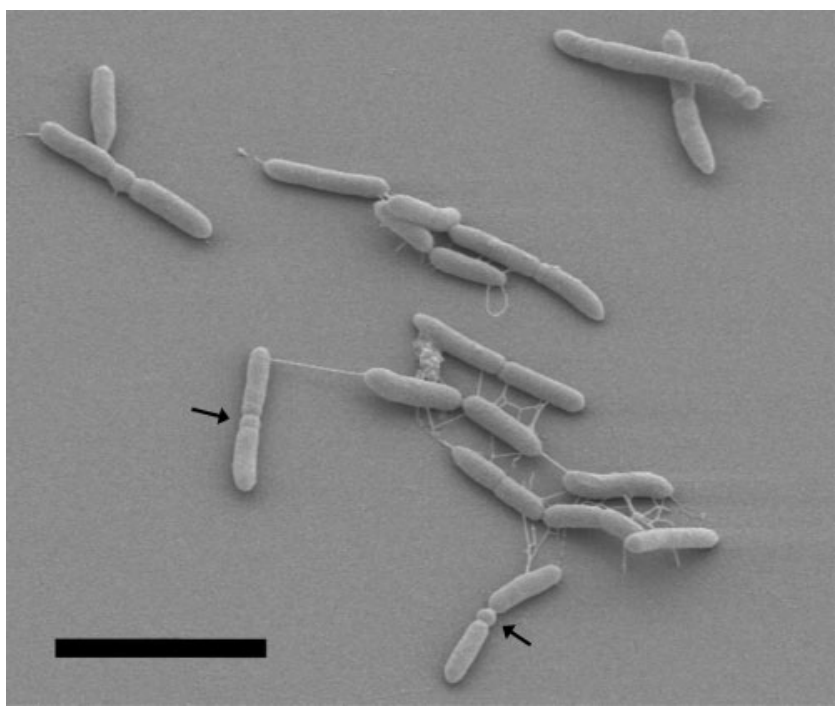

Fig. 3. Scanning electron micrographs of cells of strain JW/ IW010 ${ }^{\top}$. Arrows indicate characteristic coccoid cells observed within the chain. Bar, $5 \mu \mathrm{m}$.
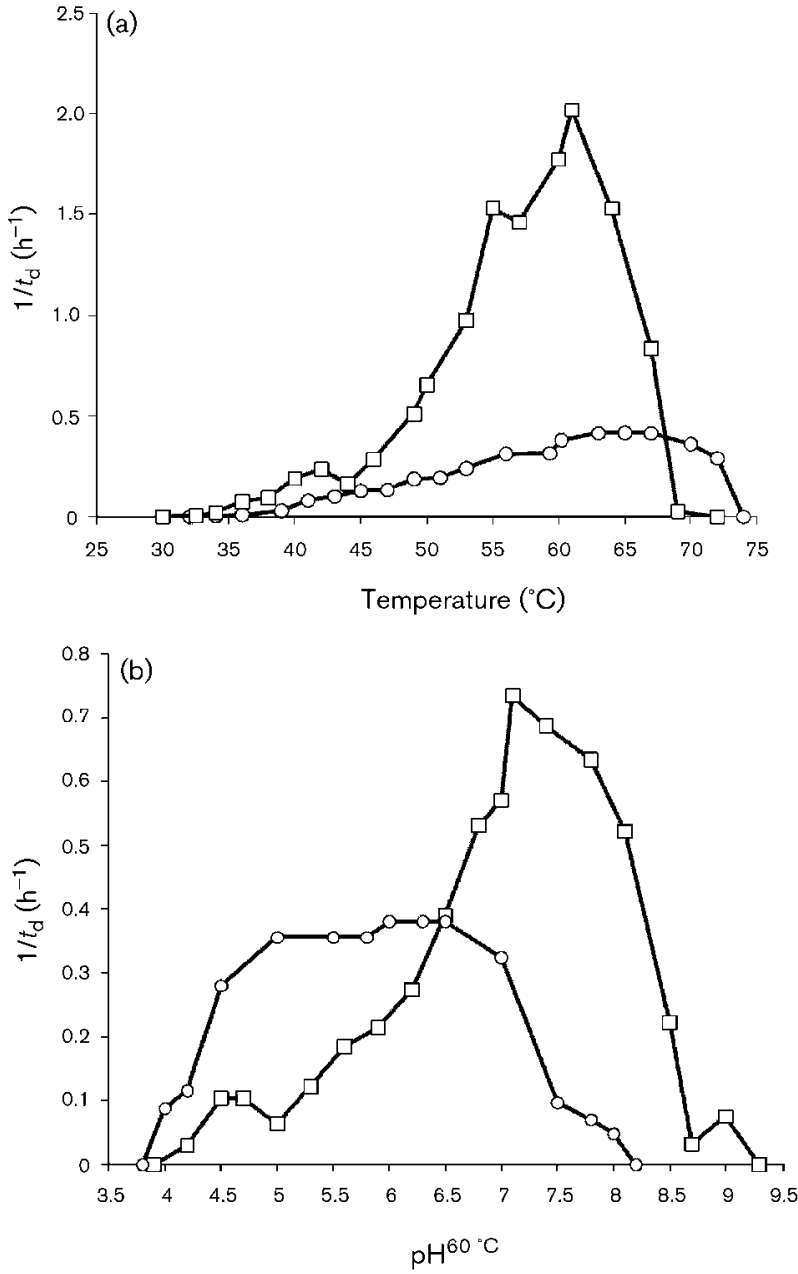

Fig. 4. Temperature and $\mathrm{pH}^{60}{ }^{\circ} \mathrm{C}$ profiles of strain $\mathrm{JW} / \mathrm{IW} 010^{\mathrm{T}}$ and Thermoanaerobacter sulfurigignens JW/SL-NZ826 ${ }^{\top}$. Growth rates over a range of temperatures (a) and $\mathrm{pH}^{60}{ }^{\circ} \mathrm{C}$ values (b) are shown. $\square$, Strain JW/IW010'; $\bigcirc$, Thermoanaerobacter sulfurigignens JW/SL-NZ826 ${ }^{\top}$ (data from Lee et al., 2007a).

increased as determined through the use of phase-contrast microscopy. At $5 \mathrm{~g} \mathrm{l}^{-1}$, yeast extract $\left(\Delta \mathrm{OD}_{600}=0.04\right)$, peptone $\left(\Delta \mathrm{OD}_{600}=0.03\right)$, Casamino acids $\left(\Delta \mathrm{OD}_{600}=0.03\right)$ and tryptone $\left(\Delta \mathrm{OD}_{600}=0.03\right)$ served as sole carbon substrates, whereas beef extract did not support growth. The ability of strain JW/IW $010^{\mathrm{T}}$ to utilize other carbon substrates was determined with substrates at a concentration of $3 \mathrm{~g} \mathrm{l}^{-1}$, supplemented with $1 \mathrm{~g}$ yeast extract $\mathrm{l}^{-1}$. Utilization was recorded as positive when $\Delta \mathrm{OD}_{600}$ was twice that of cultures containing only the basal $\left(1 \mathrm{~g} \mathrm{l}^{-1}\right)$ concentration of yeast extract. Growth of strain JW/ IW $010^{\mathrm{T}}$ was observed with inulin, cellobiose, maltose, sucrose, glucose, fructose, galactose, mannose, xylose, trehalose, mannitol, pyruvate and crotonate. Growth was not observed with casein, cellulose, xylan, starch, olive oil, pectin, lactose, arabinose, rhamnose, ribose, xylitol, sorbitol, methanol, glucuronic acid or glycerate. 
Enhanced growth of strain JW/IW $010^{\mathrm{T}}$ was not observed in media containing a headspace of $\mathrm{H}_{2} / \mathrm{CO}_{2}$, in comparison with cultures grown in the same basal media containing $1 \mathrm{~g}$ yeast extract $\mathrm{l}^{-1}$, with an $\mathrm{N}_{2}$ gas headspace. When grown with 2 g glucose $l^{-1}$ and 1 g yeast extract $l^{-1}$, strains JW/IW $010^{\mathrm{T}}$ and $1501 / 60$ produced lactic acid, acetic acid, ethanol, $\mathrm{CO}_{2}$ and $\mathrm{H}_{2}$ as fermentation end products, though in different proportions. Strain JW/IW010 primarily produced ethanol and acetate, and only a trace amount of lactic acid, yielding a simplified fermentation equation of: 1 glucose $+0.85 \mathrm{H}_{2} \mathrm{O} \rightarrow 0.85$ acetic acid + 1.15 ethanol $+2 \quad \mathrm{CO}_{2}+1.7 \quad \mathrm{H}_{2}$, whereas strain 1501/60 produced lactic acid, acetic acid and ethanol, yielding the simplified fermentation equation of: 1 glucose +0.6 $\mathrm{H}_{2} \mathrm{O} \rightarrow 0.84$ lactic acid +0.6 acetic acid +0.56 ethanol + $1.16 \mathrm{CO}_{2}+1.76 \mathrm{H}_{2}$.

The phylogenetically close neighbour, Thermoanaerobacter sulfurigignens (two isolates), exhibits resistance to $1 \mathrm{M}$ thiosulphate and $90 \mathrm{mM}$ sulphite (Lee et al., 2007a). In contrast, strain JW/IW $010^{\mathrm{T}}$ tolerated only up to $200 \mathrm{mM}$ thiosulphate (growth did not occur at or above $250 \mathrm{mM}$ ) and up to $40 \mathrm{mM}$ sulphite (no growth at or above $50 \mathrm{mM}$ ) using mineral media supplemented with $1 \mathrm{~g}$ yeast extract $1^{-1}$ and $1 \mathrm{~g}$ glucose $\mathrm{l}^{-1}$ as carbon and energy sources. The reduction of thiosulphate to sulphide was assessed by the use of lead acetate-impregnated paper. A culture that was supplemented only with yeast extract served as a control. In media containing 50 or $100 \mathrm{mM}$ thiosulphate, and $1 \mathrm{~g} \mathrm{l}^{-1}$ yeast extract and glucose, strain JW/IW $010^{\mathrm{T}}$ formed $\mathrm{H}_{2} \mathrm{~S}$ and elemental sulphur, observed as intracellular sulphur deposits, from thiosulphate. Sulphur granula could be differentiated and from spores by the little to no swelling of the mother cell, occasional multiple inclusions per cell, and the late appearance of sulphur granula in the stationary phase after spore formation (Fig. $2 \mathrm{a}$ and $\mathrm{b}$ ). The formation of elemental sulphur deposits in addition to $\mathrm{H}_{2} \mathrm{~S}$ formation is similar to what has been observed for Thermoanaerobacter italicus (Kozianowski et al., 1997), whereas Thermoanaerobacter sulfurigignens (Lee et al., 2007a, b) only produces elemental sulphur, similar to most species of Thermoanaerobacterium (Lee et al., 1993; Onyenwoke \& Wiegel, 2008; Schink \& Zeikus, 1983).

To compare the biochemical and enzymic features of strain JW/IW $010^{\mathrm{T}}$ with those of its closest recognized relative, Thermoanaerobacter sulfurigignens JW/SL-NZ826 ${ }^{\mathrm{T}}$, the BBL Crystal RGP (Becton Dickinson) system was used. The procedures used were according to the manufacturer's instructions with the modification that cells were obtained via centrifugation of $250 \mathrm{ml}$ cultures that were grown overnight (basal medium described previously, containing $2 \mathrm{~g}$ yeast extract $\mathrm{l}^{-1}$ and $4 \mathrm{~g}$ glucose $\mathrm{l}^{-1}$ ). The cells were then washed twice with a solution of the basal medium that did not contain yeast extract or other carbon substrate. Under these conditions, both strain JW/IW $010^{\mathrm{T}}$ and Thermoanaerobacter sulfurigignens JW/SL-NZ826 ${ }^{\mathrm{T}}$ tested positive for the following: hydrolysis of the glycosidic bond of 4-methylumbelliferone (4MU) $\beta$-D-glucoside, hydrolysis of the amide bond of L-methionine-7amino-4-methylcoumarin (AMC) and L-valine-AMC; hydrolysis of the aryl substituted glycoside of $o$-nitrophenyl $\beta$-D-glucoside and $p$-nitrophenyl $\beta$-D-glucoside, $p$-nitrophenyl $\beta$-D-glucoside, $p$-nitrophenyl phosphate, and $p$-nitrophenyl $\beta$-D-galactoside and $p$-nitrophenyl $\alpha$-Dgalactoside. Both taxa tested negative for the following: hydrolysis of the amide bond of L-proline-AMC, L-arginine-AMC, L-tryptophan-AMC and L-phenylalanine-AMC; hydrolysis of the glycosidic bond of $4 \mathrm{MU}$ $\beta$-cellobiose, $4 \mathrm{MU}$-phosphate, $4 \mathrm{MU} \alpha$-D-glucoside; utilization of arabinose, maltose, dextrin, mannitol, galactose, $\mathrm{N}$-acetyl-D-glucosamine, trehalose, mannose, maltotriose, ornithine; the enzymic hydrolysis of the aryl substituted glycoside of $p$-nitrophenyl $\alpha$-D-glucoside; and hydrolysis of urea and aesculin. However, the two taxa differed in that Thermoanaerobacter sulfurigignens JW/SL-NZ826 ${ }^{\mathrm{T}}$ hydrolysed the amide bond of L-pyrogluamic acid-AMC, whereas strain JW/IW $010^{\mathrm{T}}$ did not, and Thermoanaerobacter sulfurigignens JW/SL-NZ826 ${ }^{\mathrm{T}}$ hydrolysed the aryl substituted glycoside of $p$-nitrophenyl $\alpha$-cellobiose, whereas JW/ IW010 ${ }^{\mathrm{T}}$ did not.

Genomic DNA for the determination of the $\mathrm{G}+\mathrm{C}$ content was extracted using a large-scale phenol/chloroform-based procedure essentially as described by Wilson (1997), without the final caesium chloride gradient purification step. The DNA G+C content was measured by using HPLC (Mesbah et al., 1989) with the modification of Lee et al. (2005), using S1 nuclease (Invitrogen) and $0.3 \mathrm{M}$ sodium acetate ( $\mathrm{pH}$ 5.0). The DNA G $+\mathrm{C}$ content of strain $\mathrm{JW} / \mathrm{IW} 010^{\mathrm{T}}$ was $33.6 \mathrm{~mol} \%(\mathrm{SD}=0.4 ; n=9)$. Krivenko et al. (1990) reported the DNA G $+C$ content of strain 1501/60 as being $34.4 \mathrm{~mol} \%$, determined using the thermal denaturation technique (Marmur \& Doty, 1962). Using the HPLC-based method of Mesbah et al. (1989), the DNA $\mathrm{G}+\mathrm{C}$ content of strain $1501 / 60$ was $33.3 \mathrm{~mol} \%$ ( $\mathrm{SD}=0.08$; $n=4)$.

To assess the genotypic similarity between strain JW/ IW010 ${ }^{\mathrm{T}}$ and Thermoanaerobacter sulfurigignens JW/SL$\mathrm{NZ}^{2} 6^{\mathrm{T}}$, and also strains JW/IW010 ${ }^{\mathrm{T}}$ and $1501 / 60$, whole genome DNA-DNA relatedness and $\Delta T_{\mathrm{m}}$ values were determined. DNA-DNA hybridizations performed at DSMZ revealed that strain JW/IW010 ${ }^{\mathrm{T}}$ and Thermoanaerobacter sulfurigignens JW/SL-NZ826 ${ }^{\mathrm{T}}$ had $64 \%$ DNA-DNA relatedness, whereas strains JW/IW010 ${ }^{\mathrm{T}}$ and $1501 / 60$ had $87-88.0 \%$ DNA-DNA relatedness. Whole-genome $\Delta T_{\mathrm{m}}$ values between strains JW/IW010 1501/60 and Thermoanaerobacter sulfurigignens JW/SL$\mathrm{NZ} 26^{\mathrm{T}}$ were determined using the fluorimetric, SYBR Green I (Invitrogen)-based technique described by Gonzalez \& Saiz-Jimenez (2005). The mean $\Delta T_{\mathrm{m}}$ between hybridized JW/IW010 ${ }^{\mathrm{T}}$ and JW/SL-NZ826 ${ }^{\mathrm{T}}$ DNA and homologous JW/IW010 ${ }^{\mathrm{T}}$ DNA was $5.85{ }^{\circ} \mathrm{C}(n=4)$. The mean $\Delta T_{\mathrm{m}}$ between hybridized JW/IW010 ${ }^{\mathrm{T}}$ and $1501 / 60$ DNA and homologous JW/IW010 ${ }^{\mathrm{T}}$ DNA was $4.95{ }^{\circ} \mathrm{C}$ $(n=4)$. At present, $\Delta T_{\mathrm{m}}$ values of $>5{ }^{\circ} \mathrm{C}$ and DNA-DNA relatedness values of less than $70 \%$, considered along with 
phenotypic and chemotaxonomic differences, are acknowledged standards for the differentiation of species (Stackebrandt et al., 2002). In comparing strain JW/ IW010 ${ }^{\mathrm{T}}$ with Thermoanaerobacter sulfurigignens JW/SLNZ826 ${ }^{\mathrm{T}}$, the $\Delta T_{\mathrm{m}}$ value of $5.85^{\circ} \mathrm{C}$ and DNA-DNA relatedness of $64 \%$ indicated that strain JW/IW $010^{\mathrm{T}}$ and Thermoanaerobacter sulfurigignens JW/SL-NZ826 ${ }^{\mathrm{T}}$ represent separate species, which was also corroborated by phenotypic and chemotaxonomic differences. The $\Delta T_{\mathrm{m}}$ value of $4.95{ }^{\circ} \mathrm{C}$ and DNA-DNA relatedness of $87-88 \%$ demonstrate that strains JW/IW010 ${ }^{\mathrm{T}}$ and $1501 / 60$ belong to the same species.

The phospholipid fatty acid (PLFA) contents of strain JW/ IW010 ${ }^{\mathrm{T}}$ and the phylogenetically closely related taxon Thermoanaerobacter sulfurigignens JW/SL-NZ826 ${ }^{\mathrm{T}}$ were measured and compared. Cell material for lipid extraction was obtained according to previously described procedures (Zhang et al., 2004), based on the protocol of White et al. (1979). In brief, an overnight extraction commenced with a single-phase organic solvent system comprising chloroform, methanol and aqueous $50 \mathrm{mM}$ phosphate buffer $(\mathrm{pH}$ 7.4) in a ratio of $1: 2: 0.8$ (by vol.). Chloroform and nanopure water were then added to the extract to obtain a final ratio of $1: 1: 0.9$ (by vol.), resulting in a two-phase system. Neutral lipids, glycolipids and polar lipids were fractionated using a silicic acid column (Guckert et al., 1985). The polar lipids were treated with mild alkaline methanolysis to produce fatty acid methyl esters. Analyses of the fatty acid methyl esters were performed using a 6890 gas chromatograph (Agilent) with a flame-ionization detector, equipped with a $30 \mathrm{~m} \mathrm{DB}-5$ column (5\% phenyl) and programmable temperature vaporizing inlet. The temperature programme for samples in hexane was: starting at $60{ }^{\circ} \mathrm{C}, \quad 10{ }^{\circ} \mathrm{C} \mathrm{min}{ }^{-1}$ to $180{ }^{\circ} \mathrm{C}$, and $4{ }^{\circ} \mathrm{C} \mathrm{min}{ }^{-1}$ to $320{ }^{\circ} \mathrm{C}$ and hold for $20 \mathrm{~min}$. GC-MS analyses of fatty acid methyl esters were performed using an HP5890 gas chromatograph (Hewlett Packard) equipped with a $30 \mathrm{~m}$ HP5-MSI column and programmable temperature vaporizing inlet and coupled to an HP5972 mass spectrometer. The major PLFAs for strain JW/IW010 ${ }^{\mathrm{T}}$ were iso-15:0 $(53.5 \%), 15: 0(11.8 \%), 16: 0$ (7.3\%), 10-methyl 16:0 (7.3\%), and anteiso-15:0 (5.3\%). The major PLFAs for Thermoanaerobacter sulfurigignens JW/SL-NZ826 ${ }^{\mathrm{T}}$ were iso-15:0 (57.7\%), 15:0 (18.3\%), anteiso-15:0 (6.1\%), iso-17:0 (5.7\%), and 10-methyl $16: 0(5.5 \%)$. PLFA $14: 0(1.7 \%)$ was found within strain JW/IW $010^{\mathrm{T}}$ but was not detected for Thermoanaerobacter sulfurigignens JW/SL-NZ826 ${ }^{\mathrm{T}}$, analysed at the same time. Whereas both strain JW/IW $010^{\mathrm{T}}$ and Thermoanaerobacter sulfurigignens JW/SL-NZ826 ${ }^{\mathrm{T}}$ contained $18: 1 \omega 9 c$ (3.9 and $1.8 \%$, respectively), the saturated fatty acid $18: 0$ was only found within strain $\mathrm{JW} / \mathrm{IW} 010^{\mathrm{T}}$ and $18: 1 \omega 7 t$ was only detected in Thermoanaerobacter sulfurigignens JW/SL$\mathrm{NZ826}^{\mathrm{T}}$ (Table 1). The PLFA content of strain 1501/60 was also analysed; as for strain JW/IW $010^{\mathrm{T}}$, iso- $15: 0$ was the major lipid (56.9\%); however, strain $1501 / 60$ was found to have more of anteiso-15:0 (9.4\%) than 15:0
Table 1. PLFA contents (\%) of strain JW/IW $010^{\top}$ (Thermoanaerobacter uzonensis sp. nov.) and Thermoanaerobacter sulfurigignens JW/SL-NZ826 ${ }^{\top}$

ND, Not detected.

\begin{tabular}{|lcc|}
\hline PLFA & $\begin{array}{c}\text { Strain } \\
\text { JW/IW010 }^{\mathbf{T}}\end{array}$ & $\begin{array}{c}\text { Strain } \\
\text { JW/SL-NZ826 }\end{array}$ \\
\hline iso-13:0 & 1.4 & 0.9 \\
$14: 0$ & 1.7 & ND \\
iso-15:0 & 53.5 & 57.7 \\
anteiso-15:0 & 5.3 & 6.1 \\
$15: 0$ & 11.8 & 18.3 \\
$16: 0$ & 7.3 & 2.2 \\
10 -methyl $16: 0$ & 7.3 & 5.5 \\
iso-17:0 & 2.8 & 5.7 \\
$18: 1 \omega 9 c$ & 3.9 & 1.8 \\
$18: 1 \omega 7 t$ & $\mathrm{ND}$ & 1.8 \\
$18: 0$ & 5.0 & $\mathrm{ND}$ \\
Total & 100 & 100 \\
& & \\
\hline
\end{tabular}

(1.1\%), in addition to having iso-16:0 (7.0\%) and anteiso-17:0 (6.3\%), which were not detected in strain JW/IW $010^{\mathrm{T}}$ or Thermoanaerobacter sulfurigignens JW/SL$\mathrm{NZ}^{2} 6^{\mathrm{T}}$ (data not shown).

In addition, strain JW/IW $010^{\mathrm{T}}$ and Thermoanaerobacter sulfurigignens JW/SL-NZ826 ${ }^{\mathrm{T}}$ differed morphologically. Cells of strain JW/IW $010^{\mathrm{T}}$ were approximately $0.5 \mu \mathrm{m}$ in width and $2-5 \mu \mathrm{m}$ in length; occasionally cells up to $15 \mu \mathrm{m}$ in length were observed. Cells of Thermoanaerobacter sulfurigignens JW/SL-NZ826 ${ }^{\mathrm{T}}$ were much more variable, between $0.3-0.8 \mu \mathrm{m}$ in diameter and $1.2-4.0 \mu \mathrm{m}$ in length during exponential growth and, during stationary growth phase, the length of the cells increased up to $35 \mu \mathrm{m}$ (Lee et al., 2007a). Certain characteristics between strain JW/IW $010^{\mathrm{T}}$ and Thermoanaerobacter sulfurigignens JW/SL-NZ826 ${ }^{\mathrm{T}}$ were similar; e.g. the measured DNA G $+\mathrm{C}$ content of 33.6 and $34.5 \mathrm{~mol} \%$ (HPLC), respectively; cells of strains JW/ IW010 ${ }^{\mathrm{T}}$ and JW/SL-NZ826 ${ }^{\mathrm{T}}$ stained Gram-negative; and the ability to use cellobiose, maltose, sucrose, xylose, galactose, mannitol and pyruvate for growth. However, these are characteristics held by many Thermoanaerobacter species. However, significant differences between strain JW/IW010 $0^{\mathrm{T}}$ and Thermoanaerobacter sulfurigignens JW/SL-NZ826 ${ }^{\mathrm{T}}$ include the optimum $\mathrm{pH}^{60}{ }^{\circ} \mathrm{C}$ for strain JW/IW $010^{\mathrm{T}}$ of 7.1 (Fig. 4b), whereas Thermoanaerobacter sulfurigignens JW/SL-NZ826 ${ }^{\mathrm{T}}$ had a broad optimum $\mathrm{pH}^{60}{ }^{\circ} \mathrm{C}$ of 5.0-6.5 (Lee et al., 2007a). Under optimal conditions, the doubling times for strain JW/IW $010^{\mathrm{T}}$ and related strains were approximately $0.5 \mathrm{~h}$ to less than $1 \mathrm{~h}$, and thus are notably faster than the doubling times reported for Thermoanaerobacter sulfurigignens JW/SL$\mathrm{NZ826^{ \textrm {T } }}$ as well as for strain JW/SL-NZ824 $(2.4 \mathrm{~h}$ ) (Lee et al., 2007a). Metabolic differences between strains JW/IW $010^{\mathrm{T}}$ and Thermoanaerobacter sulfurigignens 
Table 2. Differential characteristics of strain JW/IW010 ${ }^{\top}$ (Thermoanaerobacter uzonensis sp. nov.) and Thermoanaerobacter sulfurigignens JW/SL-NZ826 ${ }^{\top}$

+ , Positive; -, negative.

\begin{tabular}{|c|c|c|}
\hline Characteristic & Strain JW/IW010 ${ }^{\mathrm{T}}$ & Strain JW/SL-NZ826 ${ }^{\mathrm{T}}$ \\
\hline Temperature optimum & 61 & $63-67$ \\
\hline pH $600^{60}{ }^{\circ} \mathrm{C}$ optimum & 7.1 & $5.0-6.5$ \\
\hline Cell size $(\mu \mathrm{m})$ & $0.5 \times 2-5$; up to 15 in length & $0.3-0.8 \times 1.2-4.0$; up to 35 in length \\
\hline \multicolumn{3}{|l|}{ Growth with: } \\
\hline Casamino acids & + & - \\
\hline Starch & - & + \\
\hline Pectin & - & + \\
\hline Lactose & - & + \\
\hline Methanol & - & + \\
\hline \multicolumn{3}{|l|}{ Growth in: } \\
\hline $250 \mathrm{mM}$ thiosulphate ${ }^{*}$ & - & + \\
\hline $\begin{array}{l}\text { Aryl-substituted glycoside of } p \text {-nitrophenyl } \\
\alpha \text {-cellobiose }\end{array}$ & - & + \\
\hline \multicolumn{3}{|l|}{ Presence of: } \\
\hline $18: 0$ & + & - \\
\hline $18: 1 \omega 7 t$ & - & + \\
\hline Production of lactic acid as a fermentation end product & Trace amounts & 0.9 mol per mol glucose consumed \\
\hline
\end{tabular}

${ }^{*}$ Strain JW/IW $010^{\mathrm{T}}$ grew at thiosulphate concentrations up to $200 \mathrm{mM}$ whereas Thermoanaerobacter sulfurigignens strain JW/SL-NZ826 ${ }^{\mathrm{T}}$ grew at thiosulphate concentrations up to $1 \mathrm{M}$.

$\dagger$ Strain JW/IW $010^{\mathrm{T}}$ grew at sulphite concentrations up to $40 \mathrm{mM}$ whereas Thermoanaerobacter sulfurigignens grew at sulphite concentrations up to $90 \mathrm{mM}$ sulphite (Lee et al., 2007a).

JW/SL-NZ826 ${ }^{\mathrm{T}}$ included that strain JW/IW010 ${ }^{\mathrm{T}}$ utilized Casamino acids as well as tryptone whereas Thermoanaerobacter sulfurigignens JW/SL-NZ826 ${ }^{\mathrm{T}}$ utilized neither (Lee et al., 2007a). Thermoanaerobacter sulfurigignens JW/ SL-NZ826 ${ }^{\mathrm{T}}$ was also able to utilize both starch and lactose as growth substrates whereas strain JW/IW $010^{\mathrm{T}}$ could not (see Table 2). In addition, the thiosulphate and sulphite tolerance between strain JW/IW $010^{\mathrm{T}}$ and Thermoanaerobacter sulfurigignens strains JW/SL-NZ826 ${ }^{\mathrm{T}}$ and JW/SLNZ824 is substantially different. Strain JW/IW $010^{\mathrm{T}}$ tolerated only up to $200 \mathrm{mM}$ thiosulphate and $40 \mathrm{mM}$ sulphite, whereas Thermoanaerobacter sulfurigignens exhibited a remarkable resistance to $1 \mathrm{M}$ thiosulphate and $90 \mathrm{mM}$ sulphite. Furthermore, strain JW/IW010 reduced thiosulphate to hydrogen sulphide and also converted thiosulphate to sulphur, whereas Thermoanaerobacter sulfurigignens could convert thiosulphate to elemental sulphur without any detectable sulphide production (Lee et al., 2007a). Differential characteristics of strain JW/IW $010^{\mathrm{T}}$ and Thermoanaerobacter sulfurigignens JW/SL-NZ826 ${ }^{\mathrm{T}}$ are summarized in Table 2.

In addition to strains JW/IW007, JW/IW015 and JW/HLKA15, other isolates with a high similarity to strain JW/
IW010 $0^{\mathrm{T}}$ ( $\geqslant 98 \% 16 \mathrm{~S}$ rRNA gene sequence similarity) have been found in hot springs throughout the Uzon Caldera. When the 16S rRNA gene sequences of strain JW/IW $010^{\mathrm{T}}$ and similar strains (data not shown) were compared with the sequence of the phylogenetically closely related recognized taxon Thermoanaerobacter sulfurigignens JW/ SL-NZ826 ${ }^{\mathrm{T}}$, noteworthy insertions/deletions were observed. A 7 bp region (nucleotides 183-189 of strain JW/SL-NZ826 ${ }^{\mathrm{T}}$ 16S rRNA gene sequence) is present within the Thermoanaerobacter sulfurigignens JW/SL-NZ826 ${ }^{\mathrm{T}} 16 \mathrm{~S}$ rRNA gene sequence, but is absent from the 16S rRNA gene sequence of strain JW/IW $010^{\mathrm{T}}$ and 14 similar isolates from the Uzon Caldera. An additional $4 \mathrm{bp}$ region (nucleotides 1428-1431 of the 16S rRNA gene sequence of strain JW/SL-NZ826 ${ }^{\mathrm{T}}$ ) is also present within the Thermoanaerobacter sulfurigignens JW/SL-NZ826 ${ }^{\mathrm{T}} 16 \mathrm{~S}$ rRNA gene sequence, but is absent from the 16S rRNA gene sequence of strain JW/IW $010^{\mathrm{T}}$ and 14 similar isolates from the Uzon Caldera.

Thus, strain JW/IW $010^{\mathrm{T}}$ is phenotypically, chemotaxonomically and phylogenetically different from the most closely related recognized species, Thermoanaerobacter sulfurigignens. For these reasons, strain $\mathrm{JW} / \mathrm{IW} 010^{\mathrm{T}}$ is 
proposed to represent a novel species with the name Thermoanaerobacter uzonensis sp. nov. Strain 1501/60 was described by Krivenko et al. (1990) as the type strain of the effectively published, but not recognized, taxon 'Clostridium uzonii', which herewith is included in the novel taxon Thermoanaerobacter uzonensis sp. nov.

\section{Description of Thermoanaerobacter uzonensis sp. nov.}

Thermoanaerobacter uzonensis (u.zo.nen'sis. N.L. masc. adj. uzonensis pertaining to the Uzon Caldera, Kamchatka, Far East Russia).

Cells are straight to slightly curved rods, approximately $0.5 \mu \mathrm{m}$ in width and $2-5 \mu \mathrm{m}$, and occasionally up to $15 \mu \mathrm{m}$, in length. Oval, subterminal to terminal, mother cell-distending spores are observed, though rarely. Cells have peritrichously inserted flagella and are motile. Cells stain Gram-negative and are Gram-type positive (Wiegel, 1981). Within agar-shake-roll tubes, colonies are circular, 1-2 $\mathrm{mm}$ in diameter, slightly convex and creamy white in colour. When grown on plates of carbonate-buffered basal medium with $2.3 \%$ agar within anaerobic jars at $60{ }^{\circ} \mathrm{C}$, forms colourless, nearly transparent circular colonies up to $1 \mathrm{~mm}$ in diameter. Temperature range for growth is 32.5$69{ }^{\circ} \mathrm{C}$ with an optimum at $61{ }^{\circ} \mathrm{C}$ (no growth is observed at $30{ }^{\circ} \mathrm{C}$ or below, or at $72{ }^{\circ} \mathrm{C}$ or above). $\mathrm{pH}^{60}{ }^{\circ} \mathrm{C}$ range for growth is 4.2-8.9 with an optimum at $\mathrm{pH}^{60}{ }^{\circ} \mathrm{C} 7.1$ (no growth occurs at or below $\mathrm{pH}^{60}{ }^{\circ} \mathrm{C} 3.9$, or at 9.2 or above). Chemo-organotrophic. Yeast extract, peptone, Casamino acids and tryptone support growth. In the presence of $0.1 \%(\mathrm{w} / \mathrm{v})$ yeast extract, growth occurs in the presence of inulin, cellobiose, maltose, sucrose, glucose, fructose, galactose, mannose, xylose, trehalose, mannitol, pyruvate and crotonate. Growth is not observed with beef extract, casein, cellulose, xylan, starch, olive oil, pectin, lactose, arabinose, rhamnose, ribose, xylitol, sorbitol, methanol, glucuronic acid or glycerate. Thiosulphate is converted to sulphide and also elemental sulphur. The $\mathrm{G}+\mathrm{C}$ content of the genomic DNA of the type strain is $33.6 \mathrm{~mol} \%(\mathrm{SD}=0.4$; HPLC method). Major PLFAs are iso-15:0, 15:0, 16:0, 10-methyl 16:0 and anteiso-15:0.

The type strain, JW/IW $010^{\mathrm{T}}\left(=\mathrm{ATCC}\right.$ BAA $-1464^{\mathrm{T}}=\mathrm{DSM}$ $18761^{\mathrm{T}}$ ), was isolated from a hot spring $2 \mathrm{~m}$ east of Pulsating Spring $\left(54.5007^{\circ} \mathrm{N} 160.0076^{\circ} \mathrm{E}\right)$ in the Winding Creek area, on the northern side of the central portion of the Uzon East Thermal field, Kamchatka, Far East Russia. This species is apparently widespread throughout the Uzon Caldera in various hot springs. Additional strains are 1501/ 60 (DSM 9752) and JW/IW007, JW/IW015 and JW/HLKA15 (available from the authors).

\section{Acknowledgements}

This research was supported by NSF grants MCB 0238407 (Kamchatka Microbial Observatory) to J.W., C.S.R. and C.L.Z. and MCB 0348180 (Nevada Microbial Interactions and Processes) to C. L.Z., C.S.R. and J.W. We thank M. M. Hodges and K. Lee for their assistance in the field (supported by NSF Research Experience for Undergraduate programmes: NSF-REU 034007, NSF-REU 0341906, and NSF-REU 0433510) and D. Crowe and P. Schroeder for assistance with the hot spring location coordinates. We also thank W. B. Whitman for equipment access and help with DNA G+C content determination, R. J. Maier and M.-Y. Sun for equipment access, and J. P. Euzéby for assistance with the nomenclature.

\section{References}

Felsenstein, J. (2001). PHYLIP (Phylogenetic inference package) version 3.6a2.1. Department of Genome Sciences, University of Washington, Seattle, USA.

Gonzalez, J. M. \& Saiz-Jimenez, C. (2005). A simple fluorimetric method for the estimation of DNA-DNA relatedness between closely related microorganisms by thermal denaturation temperatures. Extremophiles 9, 75-79.

Guckert, J. B., Antworth, C. P., Nichols, P. D. \& White, D. C. (1985). Phospholipid, ester-linked fatty-acid profiles as reproducible assays for changes in prokaryotic community structure of estuarine sediments. FEMS Microbiol Lett 31, 147-158.

Jukes, T. H. \& Cantor, C. R. (1969). Evolution of protein molecules. In Mammalian Protein Metabolism, pp. 21-132. Edited by H. N. Munro. New York, NY: Academic Press.

Kozianowski, G., Canganella, F., Rainey, F. A., Hippe, H. \& Antranikian, G. (1997). Purification and characterization of thermostable pectate-lyases from a newly isolated thermophilic bacterium, Thermoanaerobacter italicus sp. nov. Extremophiles 1, 171-182.

Krivenko, V. V., Vadachloriya, R. M., Chermykh, N. A., Mityushina, L. L. \& Krasilnikova, E. N. (1990). Clostridium uzonii sp. nov., an anaerobic thermophilic glycolytic bacterium isolated from hot springs in the Kamchatka peninsula. Microbiology (English translation of Mikrobiologiia) 59, 741-748.

Lane, D. J. (1991). 16S/23S rRNA sequencing. In Nucleic Acid Techniques in Bacterial Systematics, pp. 115-175. Edited by E. Stackebrant \& M. Goodfellow. Chichester, UK: John Wiley \& Sons.

Lee, Y.-E., Jain, M. K., Lee, C., Lowe, S. E. \& Zeikus, J. G. (1993). Taxonomic distinction of saccharolytic thermophilic anaerobes: description of Thermoanaerobacterium xylanolyticum gen. nov., sp. nov., and Thermoanaerobacterium saccharolyticum gen. nov., sp. nov.; reclassification of Thermoanaerobium brockii, Clostridium thermosulfurogenes, and Clostridium thermohydrosulfuricum E100-69 as Thermoanaerobacter brockii comb. nov., Thermoanaerobacterium thermosulfurigenes comb. nov., and Thermoanaerobacter thermohydrosulfuricus comb. nov., respectively; and transfer of Clostridium thermohydrosulfuricum $39 \mathrm{E}$ to Thermoanaerobacter ethanolicus. Int $J$ Syst Bacteriol 43, 41-51.

Lee, Y.-J., Wagner, I. D., Brice, M. E., Kevbrin, V. V., Mills, G. L., Romanek, C. S. \& Wiegel, J. (2005). Thermosediminibacter oceani gen. nov., sp. nov. and Thermosediminibacter litoriperuensis sp. nov., new anaerobic thermophilic bacteria isolated from Peru Margin. Extremophiles 9, 375-383.

Lee, Y.-J., Dashti, M., Prange, A., Rainey, F. A., Rohde, M., Whitman, W. B. \& Wiegel, J. (2007a). Thermoanaerobacter sulfurigignens sp. nov., an anaerobic thermophilic bacterium that reduces $1 \mathrm{M}$ thiosulfate to elemental sulfur and tolerates $90 \mathrm{mM}$ sulfite. Int J Syst Evol Microbiol 57, 1429-1434.

Lee, Y.-J., Prange, A., Lichtenberg, H., Rohde, M., Dashti, M. \& Wiegel, J. (2007b). In situ analysis of sulfur species in sulfur globules produced from thiosulfate by Thermoanaerobacter sulfurigignens and Thermoanaerobacterium thermosulfurigenes. J Bacteriol 189, $7525-7529$. 
Ljungdahl, L. G. \& Wiegel, J. (1986). Working with anaerobic bacteria. In Manual of Industrial Microbiology and Biotechnology, pp. 115-127. Edited by A. L. Demain \& N. A. Solomon. Washington, DC: American Society for Microbiology.

Marmur, J. \& Doty, P. (1962). Determination of the base composition of deoxyribonucleic acid from its thermal denaturation temperature. $J$ Mol Biol 5, 109-118.

Mesbah, M., Premachandran, U. \& Whitman, W. B. (1989). Precise measurement of the $\mathrm{G}+\mathrm{C}$ content of deoxyribonucleic acid by highperformance liquid chromatography. Int J Syst Bacteriol 39, 159-167.

Nicholas, K. B. \& Nicholas, H. B. (1997). GeneDoc: a tool for editing and annotating multiple sequence alignments v2.6.001. Distributed by the author.

Onyenwoke, R. U. \& Wiegel, J. (2008). Genus VIII. Thermoanaerobacter. In Bergey's Manual of Systematic Bacteriology (in press).

Saitou, N. \& Nei, M. (1987). The neighbor-joining method: a new method for reconstructing phylogenetic trees. Mol Biol Evol 4, 406-425.

Schink, B. \& Zeikus, J. G. (1983). Clostridium thermosulfurogenes sp. nov., a new thermophile that produces elemental sulphur from thiosulphate. J Gen Microbiol 129, 1149-1158.

Stackebrandt, E., Kramer, I., Swiderski, J. \& Hippe, H. (1999). Phylogenetic basis for a taxonomic dissection of the genus Clostridium. FEMS Immunol Med Microbiol 24, 253-258.

Stackebrandt, E., Frederiksen, W., Garrity, G. M., Grimont, P. A., Kämpfer, P., Maiden, M. C., Nesme, X., Rosselló-Mora, R., Swings, J. $\&$ other authors (2002). Report of the ad hoc committee for the re- evaluation of the species definition in bacteriology. Int J Syst Evol Microbiol 52, 1043-1047.

Thompson, J. D., Higgins, D. G. \& Gibson, T. J. (1994). Clustal W: improving the sensitivity of progressive multiple sequence alignment through sequence weighting, position-specific gap penalties and weight matrix choice. Nucleic Acids Res 22, 4673-4680.

White, D. C., Davis, W. M., Nickels, J. S., King, J. D. \& Bobbie, R. J. (1979). Determination of the sedimentary microbial biomass by extractible lipid phosphate. Oecologia 40, 51-62.

Widdel, F. \& Bak, F. (1992). Gram-negative mesophilic sulfatereducing bacteria. In The Prokaryotes, pp. 3352-3378. Edited by A. Balows, H. Trüper, M. Dworkin, W. Harder \& H. Schleifer. New York: Springer.

Wiegel, J. (1981). Distinction between the Gram reaction and the Gram type of bacteria. Int J Syst Bacteriol 31, 88.

Wiegel, J. \& Ljungdahl, L. G. (1981). Thermoanaerobacter ethanolicus gen. nov., spec. nov., a new, extreme thermophilic, anaerobic bacterium. Arch Microbiol 128, 343-348.

Wilson, K. (1997). Preparation of genomic DNA from bacteria. In Current Protocols in Molecular Biology, pp. 2.4.1-2.4.5. Edited by F. M. Ausubel, R. Brent, R. E. Kingston, D. D. Moore, J. G. Seidman, J. A. Smith \& K. Struhl. New York, NY: Greene Publishing and Wiley-Interscience.

Zhang, C. L., Fouke, B. W., Bonheyo, G. T., Peacock, A. D., White, D. C., Huang, Y. \& Romanek, C. S. (2004). Lipid biomarkers and carbonisotopes of modern travertine deposits (Yellowstone National Park, USA): implications for biogeochemical dynamics in hot-spring systems. Geochim Cosmochim Acta 68, 3157-3169. 